\title{
POST-ADOPTION CONTACT REFORM: COMPOUNDING THE STATE-ORDERED TERMINATION OF PARENTHOOD?
}

\author{
BRIAN SLOAN ${ }^{*}$
}

\begin{abstract}
The Children and Families Act 2014 pursues the twin policies of increasing the number of children adopted out of compulsory state care and reducing the scope for court-ordered contact between such children and their birth families. Building upon previous work by Dr. Kirsty Hughes and myself, this paper critically evaluates these reforms to post-adoption contact in view of the fact that adoption terminates the legal relationship of parent and child. Aspects of the analysis include the impact of the proposals on "open adoption" and child welfare in the light of the available empirical evidence, and their compatibility with both the European Convention on Human Rights and the UN Convention on the Rights of the Child.
\end{abstract}

KEYWORDS: child protection, human rights, UNCRC, ECHR, identity, law reform

\section{INTRODUCTION}

Adoption terminates the legal relationship between the child to be adopted and his or her natural parents. ${ }^{1}$ It has been described as the "most draconian interference with family life possible". ${ }^{2}$ Adoption has nevertheless been central to the child protection policy of both the current and the previous UK Governments, being seen as an ideal method of providing a suitable home environment for children who cannot remain with their birth families. Post-adoption contact could be regarded as a means of mitigating the severity of adoption by permitting a child to retain some link with his or her birth family. This article, however, sets out critically to evaluate the fact that it is current Government policy both to increase the number and speed of adoptions of children from

\footnotetext{
* College Lecturer and Fellow, Robinson College, Cambridge. An earlier version of this article was presented at a Centre for Public Law seminar at the University of Cambridge in October 2013. I am very grateful to Dr. Mark Elliott for organising the seminar and to the attendees, and especially Dr. Claire Fenton-Glynn, for their comments. I must also acknowledge the input of Dr. Kirsty Hughes, particularly since this article draws extensively upon our previous joint work on post-adoption contact. All errors are nevertheless my own.

${ }^{1}$ Adoption and Children Act 2002, s. 67. Cf. "simple adoption", a form of adoption available in France and some other civil law jurisdictions, which "does not sever the relationship with the family of origin so that the adopted child is not entirely integrated into his or her adoptive family": Explanatory Report to the European Convention on the Adoption of Children (Revised) 2008, at [63].

${ }^{2}$ Down Lisburn Health \& Social Services Trust v H [2006] UKHL 36, [2007] 1 F.L.R. 121, at [34] (Lady Hale).
} 
compulsory state foster care and to reduce the scope for post-adoption contact between such children and their birth families.

The article begins by setting out English adoption law and policy, including the reforms to the process pursued in the Children and Families Act 2014 notwithstanding the fact that this area was overhauled as recently as 2005 when the Adoption and Children Act 2002 came fully into force. It then moves to its primary concern of post-adoption contact, analysing pre-existing law and practice before criticising the changes heralded by the Children and Families Act in the light of both the principle that the child's welfare is the paramount consideration in court decisions (the "welfare principle") and the available empirical evidence on post-adoption contact.

Finally, the article conducts a "human rights audit"3 of the post-adoption contact reforms. It argues that the Children and Families Act further jeopardises English Law's compatibility with both the European Convention on Human Rights and the UN Convention on the Rights of the Child as regards its approach to post-adoption contact. In doing so, however, the article highlights the limitations of these international human rights conventions in providing a clear answer to the compatibility question.

\section{Adoption LAW \& Policy In ENGLAND \& WALES}

Adoption policy in England and Wales is dominated by the notion that the stability provided by swift adoption is generally beneficial for children who have to be removed from their parents and might otherwise drift through state-provided foster care. ${ }^{4}$ The Adoption and Children Act 2002 unashamedly aimed to bring about "more adoptions, more quickly" for children in care. ${ }^{5}$ Indeed, local authorities are placed under a duty to initiate adoption proceedings (by applying for an initial "placement order") ${ }^{6}$ where inter alia the authority is "satisfied that the child ought to be placed for adoption", 7 and in the context of the 2002 Act it has been recognised as legitimate for a local

\footnotetext{
${ }^{3}$ The term is borrowed from S. Harris-Short and J. Miles, Family Law: Text, Cases and Materials, 2nd ed. (Oxford 2011) 254 .

${ }^{4}$ See, e.g., S. Harris-Short, "Holding onto the Past: Adoption, Birth Parents and the Law in the Twenty-First Century" in R. Probert and C. Barton (eds), Fifty Years in Family Law: Essays for Stephen Cretney (Cambridge 2012) for discussion of current adoption law and policy.

${ }^{5}$ S. Harris-Short, "New Legislation: The Adoption and Children Bill - A Fast Track to Failure?" [2001] Child \& Family Law Quarterly 405, 407.

${ }^{6}$ Adoption and Children Act 2002, s. 21.

${ }^{7}$ Adoption and Children Act 2002, s. 22.
} 
authority to seek such an order "even though it recognises the reality that a search for adoptive parents may be unsuccessful". 8 The policy of securing more adoptions, pursued in spite of apparently mixed outcomes for children adopted out of care, ${ }^{9}$ can also be seen from the fact that the Act allows an adoption agency to place a child with a view to adoption by virtue of the consent of a child's parents (with parental responsibility) ${ }^{10}$ or his or her guardian, without the need for a court order, $^{11}$ and the fact that such people can provide advance consent to the final and necessary adoption order at the same time. ${ }^{12}$ If consent is not forthcoming from parents with parental responsibility, a court can dispense with the need for it if the child's welfare "requires" that it be dispensed with, ${ }^{13}$ and the adoption can proceed on the basis of welfare alone provided either that the relevant parents have at some stage consented to the process or that the criteria for state care (based on the existence or likelihood of significant harm to the child) have been made out. ${ }^{14}$ Moreover, the Act instructs the courts and adoption agencies "at all times" to "bear in mind that, in general, any delay in coming to [a] decision [relating to adoption] is likely to prejudice the child's welfare". 15

The prioritisation of adoptions obviously has profound implications for the child's birth family and his or her relationship with them, but is carried further in the Children and Families Act in the light of continued concerns that adoption is not proceeding quickly enough. ${ }^{16}$ That Act received Royal Assent in March 2014, and commencement of many of its specific adoption-related provisions will occur in stages throughout $2014 .{ }^{17}$ Section 2 of the 2014 Act will impose a duty on

${ }^{8}$ Re P (Placement Orders: Parental Consent) [2008] EWCA Civ 535, [2008] 2 F.L.R. 625, at [137] (Wall L.J., giving the judgment of the Court).

${ }^{9}$ Harris-Short, "Holding onto the Past", pp. 150-151.

${ }^{10}$ Adoption and Children Act 2002, s. 52(6).

${ }^{11}$ Adoption and Children Act 2002, s. 19.

${ }^{12}$ Adoption and Children Act 2002, s. 20. Restrictions are then placed on parents' ability to withdraw their consent and oppose the making of the final adoption order: see B. Sloan, "Conflicting rights: English Adoption Law and the Implementation of the UN Convention on the Rights of the Child” [2013] Child \& Family Law Quarterly 40, 56-57.

${ }^{13}$ Adoption and Children Act 2002, s. 52(1)(b). Consent can also be dispensed with where "the parent or guardian cannot be found or is incapable of giving consent": s. 52(1)(a).

${ }^{14}$ Adoption and Children Act 2002, s. 18, s. 21.

${ }^{15}$ Adoption and Children Act 2002, s. 1(3).

${ }^{16}$ Department for Education, An Action Plan for Adoption: Tackling Delay (London 2011). Cf. the increase of 15 per cent in the number of adoptions from care in England in the year ending March 2013 as compared to the year before: Department for Education, Statistical First Release: Children Looked After in England (Including Adoption and Care Leavers) Year Ending 31 March 2013 (London 2013).

${ }^{17}$ Inter alia, Children and Families Act, s. 9 will come into force on 22 April 2014 (Children and Families Act 2014 (Commencement No. 2) Order 2014 SI 2014/889, art. 4) while ss. 4 and 7 will commence on 13 May 2014 (SI 
an English local authority considering adoption for a given child also to consider placing the child "with a local authority foster parent who has been approved as a prospective adopter", ${ }^{18}$ albeit now only where the local authority decides that placement with a "a relative, friend or other person connected with [the child]...who is also a local authority foster parent"19 is "not the most appropriate placement" ${ }^{20}$ This placement with prospective adopters has become known as a "fostering for adoption" placement, ${ }^{21}$ and it effectively requires the local authority to consider placing the child with prospective adopters notwithstanding the very fact that the local authority do not "yet have authorisation to place the child for adoption" from either the birth parents or a court. ${ }^{22}$ Where the conditions for a "fostering for adoption" placement apply, the Act would also expressly disapply ${ }^{23}$ the local authority's statutory duty, ${ }^{24}$ inter alia, to give any further preference in foster placements to a foster parent who is also a "relative, friend or other person connected with" the child. $^{25}$

When evaluating English adoption law and practice, the UN Committee on the Rights of the Child expressed concern that "children of African descent and children of ethnic minorities sometimes face a long period waiting for adoption by a family of the same ethnic origin", ${ }^{26}$ and recommended that the state "strengthen its efforts to facilitate a situation in which children, always in their best interests, be adopted as speedily as possible, taking in due account, inter alia, [of] their cultural background". ${ }^{27}$ The Act's response to this problem of delay, however, is to remove ${ }^{28}$ the

2014/889, art. 5) and ss. 1 (in relation to England), 2-3 and 6 will commence on 25 July 2014 (SI 2014/889, art. 6). See also Children and Families Act 2014 (Commencement No. 1) Order, SI 2014/793.

${ }^{18}$ Children Act 1989, new s 26(9B)(c), inserted by Children and Families Act 2014, s. 2(3). See also Children and Families Act 2014, s. 7.

${ }^{19}$ Children Act 1989, s. 26(6)(a).

${ }^{20}$ Children Act 1989, new s 26(9B)(c), inserted by Children and Families Act 2014, s. 2(3).

${ }^{21}$ Explanatory Notes to the Children and Families Act 2014, at [53]. See, generally, D. Nickols, "Fostering for Adoption: Progress or Unjustifiable 'Fait Accompli' or Something In-between? Part 1” [2014] Family Law 190 ; D. Nickols, “Fostering for Adoption: Part 2: Policy and Potential Difficulties" [2014] Family Law 339.

${ }^{22}$ Ibid., at [54].

23 Children Act 1989, new s 26(9B)(a), inserted by Children and Families Act 2014, s. 2(3)..

${ }^{24}$ Children Act 1989, s 22C(7)(a).

${ }^{25}$ Children Act 1989, s. 22C(6)(a).

${ }^{26}$ Committee on the Rights of the Child, "Consideration of Reports submitted by State[ ] Parties under Article 44 of the Convention - Concluding Observations: United Kingdom of Great Britain and Northern Ireland" (Third and Fourth Reports) (CRC/C/GBR/CO/4, 2008), at [46].

${ }^{27}$ Ibid., at para. [47]. 
existing specific obligation to "give due consideration to the child's religious persuasion, racial origin and cultural and linguistic background" in England. ${ }^{29}$ That said, the Explanatory Notes to the Act emphasise that a local authority "will remain under a duty to have regard to the child's religious persuasion, racial origin and cultural and linguistic background, amongst other factors, where relevant", 30 and that the reform is merely "intended to avoid any suggestion that the current legislation places a child's religious persuasion, racial origin and cultural and linguistic background above the factors" listed elsewhere in the 2002 Act. $^{31}$ The 2014 Act additionally aims to increase co-operation between adoption agencies in recruiting, assessing and approving prospective adopters, ${ }^{32}$ and to reform adoption support services. ${ }^{33}$

The Government has claimed that it is not its intention that "kinship carers should be overlooked as a consequence of the clause in [what was then] the Bill concerning fostering for adoption". ${ }^{34}$ Interested parties including the Children's Commissioner and the Joint Committee on Human Rights expressed concern that this would in fact be the effect of the original Bill, ${ }^{35}$ although it contained different drafting. ${ }^{36}$ In any case, it is not clear that the current drive towards increasing the number of adoptions is consistent with Lord Neuberger's recent assertion in the Supreme Court that the "adoption of a child against her parents' wishes should only be contemplated as a last resort - when all else fails", ${ }^{37}$ which has already been very influential (alongside similar assertions) in the lower courts. ${ }^{38}$ On Lord Neuberger's analysis, "the court must be satisfied that there is no practical

${ }^{28}$ Children and Families Act 2014, s. 3. The Joint Committee on Human Rights has expressed concern about the compatibility of the original proposal with the UNCRC: Joint Committee on Human Rights, Legislative Scrutiny: Children and Families Bill; Energy Bill (H.L. Paper 29/H.C. 452, 2013), at [23]-[33].

${ }^{29}$ Adoption and Children Act 2002, s. 1(5).

${ }^{30}$ Explanatory Notes to the Children and Families Act 2014, at [56].

${ }^{31}$ Ibid., at [57].

${ }^{32}$ Children and Families Act 2014, s. 4. See, generally, Department for Education, Further Action on Adoption: Finding More Loving Homes (London 2013).

${ }^{33}$ Children and Families Act 2014, ss. 5-6.

${ }^{34}$ Joint Committee on Human Rights, Legislative Scrutiny: Children and Families Bill; Energy Bill, p. 3.

${ }^{35}$ Ibid., p. 3; paras. [13]-[22].

${ }^{36}$ Cf. Children and Families Bill 2012-13 as introduced into the House of Commons, cl. 1(3).

${ }^{37}$ Re B (Care Proceedings: Appeal) [2013] UKSC 33, [2013] 1 W.L.R. 1911, at [104]. See, generally, B. Sloan, "Loving but Potentially Harmful Parents in the Supreme Court" [2014] C.L.J. 28.

${ }^{38}$ See, eg. Re V (Children) (Long-term Fostering versus Adoption) [2013] EWCA Civ 913, [2013] 3 F.C.R. 407, at [7] (Black L.J.); Re B-S (Children) (Adoption: Leave to Oppose) [2013] EWCA Civ 1146, [2014] 1 W.L.R. 563, at [22] (Sir James Munby P.); HvG (Adoption: Appeal) [2013] EWHC 2136 (Fam), [2013] Family Law 1358, at [2] (Peter Jackson J.); Re G (A Child) (Care Proceedings: Welfare Evaluation) [2013] EWCA Civ 965, [2013] 3 F.C.R. 293, at 
way of the authorities (or others) providing the requisite assistance and support" to render adoption unnecessary. ${ }^{39}$ It is telling that the Select Committee on Adoption Legislation ("SCAL") has urged the Government "not to undermine the potential benefit of preventative programmes by focusing on adoption at the expense of early intervention", and expressed concern that "the Government's focus on adoption risks disadvantaging those children in care for whom adoption is not suitable". 40 Nevertheless, the Committee also agreed with the Government's position that "there is scope to increase the number of children benefitting from adoption". 41

The focus of this article is on decisions not about whether adoption should occur in the first place, but about contact between the adoptee and his birth family once the adoption has occurred. It could be argued, however, that the insistence on promoting adoption as a solution for looked-after children only increases the importance of recognising the link between birth parent and adopted child in appropriate cases notwithstanding the severance of the relevant legal parenthood. In spite of this, the next section of this article demonstrates that the Government has not taken this attitude.

\section{POST-ADOPTION CONTACT}

\section{A. Current Law \& Practice}

[30] (McFarlane L.J.); Re P (A Child) (Care and Placement: Evidential Basis of Local Authority Case) [2013] EWCA Civ 963, [2013] 3 F.C.R. 159, at [102] (Black L.J.); Re J (A Child) [2013] EWCA Civ 1100, at [6] (McFarlane L.J.); Re $S$ (A Child) [2013] EWCA Civ 1073, [2014] Family Law 19, at [35] (Black L.J.); Re AW (a Child: Application to revoke Placement Order: Leave to oppose Adoption) [2013] EWHC 2967 (Fam), at [37] (Pauffley J.); Re IA (a Child) (Fact Finding: Welfare: Single Hearing: Experts Reports) [2013] EWHC 2499 (Fam), (2013) 134 B.M.L.R. 6, at [98] (Pauffley J.); Re W (A Child) (Care Proceedings: Welfare Evaluation: Functions of Local Authority) [2013] EWCA Civ 1227, [2014] 1 F.C.R. 260, at [94] (Ryder L.J.); Re W (A Child) (Adoption Order: Leave to Oppose) [2013] EWCA Civ 1177, [2014] 1 F.C.R. 191, at [22] (Sir James Munby); Re C (A Child) (Appeal from Care and Placement Orders), [2013] EWCA Civ 1257, [2014] 1 F.C.R. 173, at [18] (McFarlane L.J.); Re L (Leave to Oppose Making of Adoption Order) [2013] EWCA Civ 1481, [2014] Family Law 275, at [53] (Black L.J.); Re HA (Capacity to Change) [2013] EWHC 3634 (Fam), [2014] Family Law 277, at [57] (Baker J.); Re A (Placement Order: Imposition of Conditions on Adoption) [2013] EWCA Civ 1611, [2014] Family Law 279, at [39] (McFarlane L.J.); RO v A Local Authority [2014] EWHC 97 (Fam), at [11] (Keehan J.); The Prospective Adopters v IA and London Borough of Croydon [2014] EWHC 331 (Fam), at [28] (Moor J.). See, generally, L. Sprinz, “Adoption in 2014” [2014] Family Law 335.

${ }^{39}$ [2013] UKSC 33, at [105].

${ }^{40}$ Select Committee on Adoption Legislation, Adoption: Post-Legislative Scrutiny Report (H.L. Paper 127, 2013$)$, p. 5.

${ }^{41}$ Ibid., at para. [24]. 
It is necessary to begin with an analysis of law and practice as they stand pending the entry into force of the post-adoption contact provisions in the 2014 Act. Historically, post-adoption contact was effectively considered to be anathema to the nature of adoption. The prevailing view, as J.C. Hall expressed it in 1987, was that "continued access by a natural parent is repugnant to the purpose of adoption, which is to effect the complete legal transplant of the child from one family to another". ${ }^{42}$ There has, however, been something of a move towards "open adoption", 43 involving the freer exchange of information between the parties to an adoption as an alternative to the secrecy that traditionally characterised the process, which has called into question the "transplant" model. ${ }^{44}$ While the SCAL claims that practice on the issue "varies considerably", 45 "[m]ost children now adopted in England and Wales are planned to have some form of contact with members of their birth family", ${ }^{46}$ reflecting the increasing age of adopted children, the consequent fact that more of them will remember, and/or become curious about, their birth families, and the perceived benefits of post-adoption contact. ${ }^{47}$ Contact of this sort will usually take an indirect form, ${ }^{48}$ such as letterbox contact, which one adoption agency defines as "an arrangement where adoptive parents, birth families and adopted children agree to exchange letters, photographs, cards and/or gift vouchers", mediated by the agency. ${ }^{49}$

But in spite of the pragmatic approach taken by adoption agencies, courts remained resistant to the imposition of such contact against the wishes of the adoptive family. ${ }^{50}$ Since the 2002 Act obliges the court to consider "whether there should be arrangements for allowing any person contact with the child" before making an adoption order, ${ }^{51}$ there was a chance that the courts could have

\footnotetext{
42 J.C. Hall, "Problems of adoption and custodianship" [1987] C.L.J. 40, 42.

${ }^{43}$ See, e.g., B. Lindley, “Open Adoption - Is the Door Ajar?” [1997] Child \& Family Law Quarterly 115.

${ }^{44}$ See, e.g., K. O’Halloran, The Politics of Adoption: International Perspectives on Law, Policy \& Practice, 2nd ed. (Dordrecht 2009), pp. 43-44.

${ }^{45}$ Select Committee on Adoption Legislation, Adoption: Post-Legislative Scrutiny Report, at [260].

46 E. Neil, "Post-Adoption Contact and Openness in Adoptive Parents' Minds: Consequences for Children's Development” (2009) 39 British Journal of Social Work 5, 6.

${ }^{47}$ But see C. Smith and J. Logan, “Adoptive Parenthood as a 'Legal Fiction' - Its Consequences for Direct PostAdoption Contact" [2002] Child \& Family Law Quarterly 281 for an account of the differing views on this issue.

${ }^{48}$ Select Committee on Adoption Legislation, Adoption: Post-Legislative Scrutiny Report, at [255].

${ }^{49}$ London Borough of Richmond Upon Thames, Adoption Contact: Information for Birth Relatives (date unknown), p. 2.

${ }^{50}$ See, e.g., Re V (A Minor) (Adoption: Consent) [1987] Fam. 57.

51 Adoption and Children Act 2002, s. 46(6). Similar obligations are imposed when the court is making a placement order: s. 27(4)(a).
} 
been prompted to change their approach following its being brought into force in 2005. As a matter of purely domestic law, it was clear that the child's welfare was to be treated as the "paramount" consideration in decisions about post-adoption contact, whether by virtue of the older Children Act 1989 or the 2002 Act. ${ }^{52}$ As ever, ${ }^{53}$ however, the real question was what that meant.

In its 2008 decision in Re P (Placement Orders: Parental Consent), ${ }^{54}$ the Court of Appeal considered contact in relation to adoption, albeit "with caution" 55 since the contact issue was "not determinative of the appeal" ${ }^{56}$ It concluded that it was:

...not...a proper exercise of the judicial powers given to the court under the 2002 Act to leave contact between the [relevant] children themselves, or between the children and their natural parents, to the discretion of the local authority and/or the prospective carers of [the two siblings who were the subjects of the proceedings], be they adoptive parents or foster carers. $^{57}$

This could have heralded a much more interventionist attitude in contact decisions related to adoption. But the Court in that case was largely concerned with its jurisdiction to order contact during placement for adoption under the 2002 Act. Contact at the placement stage, before the adoption has occurred, is obviously distinct from post-adoption contact and has much in common with contact while a child is simply in foster care. Moreover, the subsequent decision of $\operatorname{Re} C$ ( $A$ Child) (Indirect Contact), which concerned provision of an annual photograph to the (birth) father of a child being placed for adoption, demonstrates that indirect contact may not necessarily be ordered even when a child has merely been placed for adoption. ${ }^{58}$ The Court of Appeal in $R e C$ held that in making the order stipulating the provision of the photograph "without hearing response from the local authority and [initially] without reasoning his conclusion", the Recorder had paid "scant regard to the interests and rights of the child"59 and ignored important evidence "to the effect generally that indirect contact between father and child should be in consultation with, and

\footnotetext{
52 Adoption and Children Act 2002, s. 1; Children Act 1989, s. 1.

${ }^{53}$ See, e.g., H. Reece, “The Paramountcy Principle: Consensus or Construct?” (1996) 49 Current Legal Problems 267.

${ }^{54}$ [2008] 2 F.L.R. 625.

${ }^{55}$ Ibid., at para. [54].

${ }^{56}$ Ibid., at para. [141].

${ }^{57}$ Ibid., at para. [153] (Wall L.J., giving the judgment of the Court).

${ }^{58}$ [2012] EWCA Civ 1281, [2013] 2 F.L.R. 272.

${ }^{59}$ Ibid., at para. [3].
} 
impliedly subject to...the approval of[,] the child's therapist" ${ }^{60}$ It does appear that there were serious procedural problems with the case, and the Court of Appeal's short judgment allowing the local authority's appeal is at least focused on genuine concerns about the particular child's welfare.

In spite of its focus on pre-adoption contact, the Court of Appeal in $R e P$ also conducted a thorough review of the authorities on post-adoption contact and concluded (technically obiter) that "[a]1l this...now falls to be revisited" in the light of the contact provisions and the particular meaning of welfare contained in the 2002 Act. $^{61}$ While the Court did not know whether its "views on contact on the facts of this particular case presage[d] a more general sea change in post-adoption contact overall", ${ }^{62}$ its judgment noted that "the 2002 Act envisages the court exercising its powers to make contact orders post adoption, where such orders are in the interests of the child concerned". 63

In the subsequent case of Re J (A Child) (Adopted Child: Contact), ${ }^{64}$ however, the Court of Appeal was adamant that the ultimate jurisdiction to make a post-adoption contact order was still contained the Children Act $1989,{ }^{65}$ under which the older, conservative approach to the matter had prevailed. This meant that the issue of post-adoption contact was not governed by the "extended meaning" of welfare in the 2002 Act, ${ }^{66}$ which specifically directs the court to consider the effect of ceasing to be a member of the birth family and the child's relationships with relatives as aspects of the child's welfare ${ }^{67}$ It also confirmed that post-adoption contact was not directly subjected to the change in the importance of welfare heralded by the 2002 Act, whereby it became the "paramount" rather than merely the "first" consideration in relation to certain decisions as regards adoption. ${ }^{68}$ Lord Neuberger M.R. reaffirmed in the judgment of the Court that "it is 'extremely unusual' to

\footnotetext{
${ }^{60}$ Ibid., at para. [3].

${ }^{61}$ [2008] EWCA Civ 535, at [147] (Wall L.J., giving the judgment of the Court).

62 [2008] EWCA Civ 535, at [154].

${ }^{63}$ Ibid.

${ }^{64}$ [2010] EWCA Civ 581, [2011] Fam. 31. For a detailed analysis of this case, see K. Hughes and B. Sloan, "Postadoption Photographs: Welfare, Rights and Judicial Reasoning” [2011] Child \& Family Law Quarterly 393.

${ }^{65}$ [2010] EWCA Civ 581, at [5]. See Hughes and Sloan, "Post-adoption Photographs", pp. 398-402 for discussion.

${ }^{66} \operatorname{Re} C$ (A Child) (Adoption: Duty of Local Authority) [2007] EWCA Civ 1206, [2008] Fam. 54, at [18] (Arden L.J.).

${ }^{67}$ Adoption and Children Act 2002, s. 1(4)(c) and s. 1(4)(f).

${ }^{68}$ Cf. Adoption Act 1976, s. 6.
} 
make an order [for contact] with which the adoptive parents are not in agreement", ${ }^{69}$ applying the test set down in Re R (Adoption: Contact) immediately before the 2002 Act had come into effect. ${ }^{70}$

The test for the substantive decision on post-adoption contact differed significantly from that applied when granting permission to apply for such contact before the advent of the 2014 Act. As the law stands before the entry into force of the Act's post-adoption contact provisions, the leave of the court is required where (as in $R e J$ ) the natural parents make a free-standing application for postadoption contact after the adoption order occurs rather than making one simultaneously with the application for the adoption order, since they are no longer legal parents in the former scenario. ${ }^{71}$ In its 2011 judgment in $\operatorname{Re} B$ (Child), the Court of Appeal held that leave would be granted where there is "something that merits investigation", 72 since "[ $t]$ he grant of permission does nothing but allow [the applicant] to cross the threshold", even though the court was reguired to consider any risk of harm to the child alongside the applicant's connection and the nature of the application. ${ }^{73}$ It will be seen, however, that this generous approach to the granting of leave has been threatened by the Children and Families Act.

On the facts of Re $J$, the Court refused to order that the natural parents who had consented to the adoption of their infant should receive and retain an annual photograph of the child in the face of opposition from the adoptive parents. Priority was given to the stability of the placement in the light of the adoptive parents' fears that it could be disrupted by the retention of the photographs, in spite of the fact that the judge below had described those fears as "understandable but rather farfetched". ${ }^{74}$ Dr. Hughes and I criticised the decision for failing adequately to distinguish the welfare of the child from the wishes of the adoptive parents, as well as giving insufficient consideration to international human rights norms. ${ }^{75}$

$R e J$ does not mean that an opposed post-adoption contact application will never succeed under the pre-2014 Act law. In MF v London Borough of Brent, Ryder L.J. (sitting in the Family Division of the High Court) made an order for direct contact between a seven-year-old would-be adoptee and members of his birth family where the order (but not the contact itself) was opposed by

\footnotetext{
${ }^{69}$ [2010] EWCA Civ 581, at [26] (Lord Neuberger M.R., giving the judgment of the Court). See also Re T (A Child) (Adoption: Contact) [2010] EWCA Civ 1527, [2011] 1 F.L.R. 1805.

${ }^{70}$ [2005] EWCA Civ 1128, [2006] 1 F.L.R. 373.

${ }^{71}$ Children Act 1989, s. 10, , it being unlikely that s. 10(5)(b) will apply.

72 [2011] EWCA Civ 509, [2011] 2 F.L.R. 1179, at [9] (Thorpe L.J.), ; Children Act 1989, s. 10(9).

73 Ibid.

${ }^{74}$ [2010] EWCA Civ 581, at [17].

${ }^{75}$ Hughes and Sloan, "Post-adoption Photographs".
} 
the eventual adopter. ${ }^{76}$ In spite of Lord Neuberger's judgment in Re J, Ryder L.J. had reference to both the 1989 Act and the 2002 Act in reaching his conclusion in $M F$, since he asserted both that the 2002 Act "envisages situations like this case where a section 8 Children Act 1989 application is made for contact which is heard at the same time as the application for an adoption order", ${ }^{77}$ and that the relevant child's "welfare throughout his life requires the maintenance of a relationship with his maternal grandmother and sister through whom there will be a relationship with his extended birth family". ${ }^{78}$ Ryder L.J. held that the adoption and contact orders were "inextricably linked on the facts of this case", that both orders were "necessary", and that the "success of the adoption order is in part dependent upon a minimum level of contact with [the child's] birth family[,] particularly his sister and maternal grandmother". ${ }^{79}$ Ryder L.J.'s assessment of the evidence is admirable, but his judgment might legitimately be criticised for failing to engage with the details of the case law. He did cite $R e R$ and $R e J$, but he also cited $R e P$ and omitted to explain precisely how $M F$ was sufficiently "unusual" to merit departure from Lord Neuberger's default approach. ${ }^{80}$ It may also be significant that the relevant child was older than the one in $R e J$, and that in $M F$ contact was ordered not with the child's birth parents but with other members of the family. ${ }^{81}$

While cases are self-evidently fact-dependent, $R e J$ must ultimately be taken as representing the dominant legal position before the modifications heralded by the 2014 Act, such that it will be "extremely unusual" for post-adoption contact to be ordered against the wishes of the adoptive parents. As it stands, the law therefore diverges significantly from social work practice, moves close to imposing a presumption against ordered contact, takes a rather narrow view of a child's best interests and carries an air of futility since an order is unlikely to be made in the very sort of case where it is most likely to be necessary. Indeed, one judge has recently referred to the "exceptional nature of contact orders together with adoption orders". ${ }^{82}$ It will be seen in the next section, however, that this position was still apparently insufficiently limiting for the Government and one of its prominent advisors.

\footnotetext{
${ }^{76}$ [2013] EWHC 1838 (Fam), [2014] 1 F.L.R. 195.

${ }^{77}$ Ibid., at para. [28(viii)].

${ }^{78}$ Ibid., at [28(viii)].

${ }^{79}$ Ibid., at [34].

${ }^{80}$ Ibid., at [28(viii)].

${ }^{81}$ See Select Committee on Adoption Legislation, Adoption: Post-Legislative Scrutiny Report, at [264]-[269] on the distinctive and particular importance of sibling contact as compared to contact with birth parents.

${ }^{82} N v B$ [2013] EWHC 820 (Fam), [2014] 1 F.L.R. 369, at [33] (Theis J.).
} 
Changes are made to the law on post-adoption contact by the Children and Families Act. Section 9 of the Act inserts new sections $51 \mathrm{~A}$ and $51 \mathrm{~B}$ concerning post-adoption contact into the 2002 Act. $^{83}$ Some changes to post-adoption contact would be necessary as a result of the 2014 Act's abolition of "residence" and "contact" orders under the section 8 of the Children Act 1989 (generally used for a child whose parents do not live together but remain both remain legal parents) and their replacement with a single "child arrangements order". ${ }^{84}$ Indeed, it is logical that the 2002 Act's specific assertion that the provisions governing contact during placement for adoption do not "prevent an application for a contact order under section 8 of the 1989 Act being made where the application is to be heard together with an application for an adoption order" is removed by the Act. ${ }^{85}$ Other, more substantive, changes are also made, in spite of the SCAL's assertion that it had received no evidence that any change to the legislative framework was required. ${ }^{86} \mathrm{~A}$ significant limitation of its report, however, is that its evidence hearings were concluded before the specific text of the proposed sections $51 \mathrm{~A}$ and $51 \mathrm{~B}$ were published. ${ }^{87}$

Several of the provisions in the Act reflect the view expressed in the foreword to the relevant Government consultation paper by Sir Martin Narey, the ministerial adviser on adoption known for his "unequivocally pro-adoption" stance, ${ }^{88}$ that post-adoption contact "harms children too often". ${ }^{89}$ That paper proceeded to suggest legislative change without any real consideration of the courts' current approach to ordering post-adoption contact, and the Government retained its view on the need for change in several respects after the consultation process culminating in the relevant aspects of the Children and Families Act. ${ }^{90}$ This was in spite of the fact that in extensive empirical work Neil et al found "little evidence that birth family contact has any great impact on broad outcomes of adoption such as placement breakdown, relationships with adoptive parents and

\footnotetext{
${ }^{83}$ Children and Families Act 2014, s. 9(1). See also s. 1, concerning the facilitation of contact between certain adoptive and birth relatives of a person adopted before the entry into force of the 2002 Act.

${ }^{84}$ Children and Families Act 2014, s. 12.

${ }^{85}$ Children and Families Act 2014, s. 9(3), repealing Adoption and Children Act 2002, s. 26(5).

${ }^{86}$ Select Committee on Adoption Legislation, Adoption: Post-Legislative Scrutiny Report, at [256].

${ }^{87}$ Ibid., at [263].

${ }^{88}$ Harris-Short, "Holding onto the Past", p. 149.

${ }^{89}$ Department for Education, Contact Arrangements for Children: A Call for Views (London 2012), p. 2.

${ }^{90}$ Cf. Department for Education, Call for Views: Adoption Contact Arrangements and Sibling Placements. Summary of Feedback and Government Response (London 2013).
} 
children's general development". ${ }^{91}$ While acknowledging that "contact, even when wanted, can be a mixed experience" for adopted children, ${ }^{92}$ they cited evidence that adopted children remaining in touch with birth relatives "in general...emerged as young adults with a sense of belonging in their new family and a realistic view of their birth family", 93 and that many who were unhappy about contact felt as they did because it had stopped or because they did not have contact with particular birth relatives. ${ }^{94}$ Most significantly, Neil et al emphasised the value of "individualised decisionmaking", and argued that there was "no need to change legislation in the direction of restricting contact", 95 albeit that they did make suggestions for improvement in practice. ${ }^{96}$ They went so far as to express concern that "a return to the more closed adoption practices of the past could actually bring about an increase in unmediated and unsolicited contact between children and their birth relatives". 97

In any case, where a local authority has placed or was authorised to place a child for adoption, ${ }^{98}$ the 2014 Act gives the court a specific power to make an order concerning postadoption contact "[w]hen making the adoption order or at any time afterwards" (effectively replacing the current mechanism of the section 8 contact order). ${ }^{99}$ The new post-adoption contact order could be positive, "requiring" the adoptive parents "to allow the child to visit or stay with the person named in the order..., or for the person named in that order and the child otherwise to have contact with each other". ${ }^{100}$ But it could also be negative, "prohibiting the person named in the order...from having contact with the child", ${ }^{101}$ and it could be made subject to "any conditions the court thinks appropriate". ${ }^{102}$ The person "named in the order", i.e. the person on whom the right to contact is conferred or who is prohibited from having contact, must fall into a recognised category.

\footnotetext{
${ }^{91}$ E. Neil et al, "Contact Arrangements for Adopted Children: What can be Learned from Research?” (Norwich 2012), at [13]. See also Smith and Logan, "Adoptive Parenthood as a 'Legal Fiction"”.

${ }^{92}$ Neil et al, "Contact Arrangements for Adopted Children", at [11].

93 Ibid.

${ }^{94}$ Ibid., at para. [16].

${ }^{95}$ Ibid., p. 1.

${ }^{96}$ Ibid., at para. [25].

${ }^{97}$ Ibid., at para. [24].

98 Adoption and Children Act 2002, s. 51A(1)(a). The use of Children Act 1989, s. 8 to make provision for postadoption contact is to be prohibited in such circumstances: Adoption and Children Act 2002, s. 51A(8).

${ }^{99}$ Adoption and Children Act 2002, s. 51A(2).

${ }^{100}$ Adoption and Children Act 2002, s. 51A(2)(a).

101 Adoption and Children Act 2002, s. 51A(2)(b).

${ }^{102}$ Adoption and Children Act 2002, s. 51B(1)(b).
} 
The relevant categories are a person who "(but for the child's adoption) would be related to the child by blood (including half-blood), marriage or civil partnership", ${ }^{103}$ a former guardian, ${ }^{104}$ a person who had parental responsibility for the child immediately before the making of the adoption order, ${ }^{105}$ a person who was entitled to apply for contact during placement by virtue of subsisting contact, residence or inherent jurisdiction arrangements at the time (inter alia) ${ }^{106}$ the local authority was authorised to place the child, ${ }^{107}$ and a person with whom the child has lived for at least a year in certain circumstances. ${ }^{108}$ The framing of the category including blood relatives is interesting given the general attitude to the birth family displayed the Act, since surely the birth family remain related to the child by blood irrespective of the child's adoption.

Significantly, while the adoptive parents ${ }^{109}$ and the child ${ }^{110}$ could apply for the new order without leave (presumably largely for the purposes of applying for a negative order in the case of the adoptive parents), all other applicants including the birth parents would be obliged to seek leave to apply for the new post-adoption contact order from the court. This removes the distinction as regards leave currently in place between a contact application made simultaneously with an adoption application and one made in subsequent proceedings, such that the change is at least rational. But it arguably prejudices the child's relationship with birth parents still further.

In a reform that is at least symbolically important, when deciding whether to grant leave to apply for post-adoption contact under the proposed section 51A(5), the court would be placed under a specific obligation to consider "any risk there might be of the proposed application disrupting the child's life to such an extent that he or she would be harmed by it", , mirroring the previous language in the more limited circumstances where leave was required but without including the nature of the application. This could be seen as a further setback for "open adoption". In addition to these considerations, the court must unsurprisingly take account of the applicant's "connection with the child" 111 and "any representations made to the court" by the child or the adoptive parents. ${ }^{112}$

\footnotetext{
${ }^{103}$ Adoption and Children Act 2002, s. 51A(3)(a).

${ }^{104}$ Adoption and Children Act 2002, s. 51A(3)(b).

105 Adoption and Children Act 2002, s. 51A(3)(c).

106 The relevant time can also be when the local authority in fact placed the child if the child was then less than six weeks old: Adoption and Children Act 2002, s. 26(1), (3)(c)-(e).

${ }^{107}$ Adoption and Children Act 2002, s. 51A(3)(d), cross-referring to s. 26(3)(c)-(e).

${ }^{108}$ Adoption and Children Act 2002, s. 51A(3)(e). The period need not be continuous, but must not have begun more than five years before the application: s. $51 \mathrm{~A}(7)$.

${ }^{109}$ Adoption and Children Act 2002, s. 51A(4)(a).

${ }^{110}$ Adoption and Children Act 2002, s. 51A(4)(b).

${ }^{111}$ Adoption and Children Act 2002, s. 51A(5)(b).
} 
Decisions on post-adoption contact would expressly governed by the welfare checklist in section 1 of the 2002 Act, ${ }^{113}$ reversing the Court of Appeal's conclusion in Re J (Adopted Child: Contact) that the checklist in section 1 of the Children Act 1989 governed the matter. ${ }^{114}$ This adds clarity to the law and recognises that decisions on post-adoption contact, and not only on adoption itself, have life-long implications. That recognition, however, is undermined by the Act's restrictive approach to leave.

The Explanatory Notes to the Act clearly assert that the reforms to post-adoption contact have "the aim of reducing the disruption that inappropriate contact can cause to adoptive placements", ${ }^{115}$ even if the Parliamentary Under Secretary of State for Children and Families insisted that what is now the Act enables birth parents and relatives "to apply to the court for contact orders where they feel it is necessary, and where such contact would genuinely be helpful and beneficial to the child". ${ }^{116}$ The reduction was pursued in spite of the SCAL's conclusion, while recognising that disruption can be damaging, that there was "general agreement" among its sources of evidence that legislation could not "provide a suitable for remedy" for such disruption where it occurred. ${ }^{117}$ This, in turn, was consistent with Neil et al's response to the original consultation exercise, and there is a significant chance that the changes to permission would either have no effect or have more of an effect than was intended.

It would of course be ridiculous for a judge steadfastly to avoid considering the risk specified in section 51A(5) even under the pre-2014 Act law, and the fact that the ordering of postadoption contact is currently limited to "extremely unusual" cases arguably minimises the practical effect of the reform and may render it pointless. Moreover, the change introduced by the Act in relation to post-adoption contact is less dramatic than its dilution of the duty to promote contact while the child is merely in foster care. ${ }^{118}$ It also falls short of the formal presumption against postadoption contact (once it is clear that a child will be adopted) that was originally proposed. ${ }^{119}$

On the other hand, the Act's inclusion of the instruction about disruption in spite of its clear relevance under the current law, combined with the reasonable assumption on the part of future

\footnotetext{
${ }^{112}$ Adoption and Children Act 2002, s. 51A(5)(c).

${ }^{113}$ Children and Families Act 2014, s. 9(2), amending Adoption and Children Act 2002, s. 1(7)(a).

${ }^{114}$ [2010] EWCA Civ 581, at [5] (Lord Neuberger M.R., giving the judgment of the Court).

${ }^{115}$ Explanatory Notes to the Children and Families Act 2014, at [8].

${ }^{116}$ Public Bill Committee (Bill 131) 2012-13, col. 252 (14 March 2013).

${ }^{117}$ Select Committee on Adoption Legislation, Adoption: Post-Legislative Scrutiny Report, at [259].

${ }^{118}$ Children and Families Act, 2014, s. 8.

${ }^{119}$ Department for Education, Contact Arrangements for Children: A Call for Views, p. 18.
} 
interpreters that section 9 is intended to have some substantive effect, risks suggesting that postadoption contact should be ordered even less readily that it already is, and even suggesting that local authorities should not encourage it where it does not need to be ordered as they currently do. At the Committee Stage in the House of Lords, Baroness Hamwee admirably attempted to balance the proposed section 51A by inserting an express requirement that the court consider "the benefit to the child of an order" for post-adoption contact when deciding upon a leave application. ${ }^{120}$ She was persuaded to withdraw her proposed amendment by a Government whip on the basis that the potential benefit of post-adoption contact is already to be considered by virtue of the welfare principle in section 1 of the 2002 Act and of an assertion (made without reference to any source) that contact is harmful for twice as many children as for whom it is beneficial. But the danger of over-interpretation of the distinctly negative emphasis in the section is particularly acute given that the instruction about considering harm relates to the increased need to consider leave and the mere application for post-adoption contact, jeapordising the legitimately low threshold exemplified by $R e$ $B$, and not even to the substantive decision taken on the full merits of the case.

An analogy can be drawn with the Family Justice Review's concerns about a proposed legislative presumption (outside the context of adoption) that a child's welfare is furthered through the involvement of both parents in his life, albeit that in that case a presumption of some sort appears on the face of the Act. ${ }^{121}$ The Government pursued that reform in spite of the Review's misgivings that legislative change of this sort could create a "perception that there is a parental right to substantially shared or equal time for both parents", ${ }^{122}$ citing the Australian experience of such a change. ${ }^{123}$ A balancing and clarifying amendment was at least successfully added to the relevant section, ${ }^{124}$ contrasting with the fate of Baroness Hamwee's amendment on post-adoption contact.

The court will be able to make a negative post-adoption contact order of its own motion under the Act when making an adoption order, but cannot make a positive one in that way. ${ }^{125}$ The inability to make an order for contact on its own initiative, when taken alongside the restrictive leave requirements that will be imposed on birth parents by the Act, rather dilutes the court's duty

\footnotetext{
${ }^{120}$ HL Deb. vol. 748 cols. GC 167-69 (14 October 2013).

${ }^{121}$ Children and Families Act 2014, s. 11.

${ }^{122}$ D. Norgrove et al, Family Justice Review: Final Report (London 2011), at [4.23].

${ }^{123}$ See H. Rhoades, "Legislating to Promote Children's Welfare and the Quest for Certainty” [2012] Child \& Family Law Quarterly 158 for discussion. Cf. F. Kaganas, “A Presumption that 'Involvement' of Both Parents is Best: Deciphering Law's Messages” [2013] Child \& Family Law Quarterly 270.

${ }^{124}$ Children Act 1989, s. 1(2B), inserted by Children and Families Act 2014, s. 11(2).

${ }^{125}$ Adoption and Children Act 2002, s. 51A(6).
} 
to "consider whether there should be arrangements for allowing any person contact with the child" before making an adoption order. ${ }^{126}$ Admittedly, however, a court would be unlikely seriously to consider ordering contact where no-one had made an application for it. By analogy with the courts' approach to contact with a non-resident legal parent, ${ }^{127}$ it is unlikely to be thought generally workable or consistent with a child's best interests to order contact between that child and someone who did not want to have such contact, and Marshall has sought to defend a mother's right to privacy and anonymity in relation to adoption following a concealed birth. ${ }^{128}$ That said, it would be odd if birth parents were to be given the near-veto on post-adoption contact that I have argued should not be given to adoptive parents, and ordering indirect contact with a reluctant birth parent could conceivably be appropriate in some cases in a way that ordering direct contact is unlikely to be.

Of course, there are some adopted children for whom even indirect and infrequent contact with birth family members would be inappropriate, particularly if they have suffered intentional abuse at the hands of such people. There are other, less relationship-oriented, means through which such children can receive information about their biological origins than contact of any form. ${ }^{129}$ But where parenting has been "merely" negligent or deficient, perhaps as a result of mental illness, it is surely appropriate at least to investigate whether the ordering of post-adoption contact would serve the long-term interests of the particular child and (to a lesser extent) ${ }^{130}$ the birth parents, rather than simply following the wishes of the adoptive parents in almost all cases and reducing the power of the courts as the Act arguably does. It is significant that Sir Martin Narey suggested to the SACL

${ }^{126}$ Adoption and Children Act 2002, s. 46(6).

${ }^{127}$ See, e.g., Re L (a child) (Contact: Domestic Violence) [2000] 2 F.C.R. 404, 437 (Thorpe L.J.).

128 J. Marshall, "Concealed Births, Adoption and Human Rights Law: Being Wary of Seeking to Open Windows into People's Souls" [2012] C.L.J. 325.

${ }^{129}$ The 2002 Act contains a framework regulating the disclosure of information by adoption agencies (Adoption and Children Act 2002, ss. 56-65 and ch. 5; see A. Bainham and S. Gilmore, Children: The Modern Law, 4th ed. (Bristol 2013), pp. 698-704 for a summary). For example, when an adopted person reaches the age of 18 (Adoption and Children Act 2002, s. 60(1)), he has the right inter alia to receive "any information which would enable him to obtain a certified copy of the record of his birth" (s. 60(2)(a)) unless the High Court orders otherwise on the basis that "the circumstances are exceptional" (s. 60(3)). That said, the 2002 Act can be criticised for stopping short of conferring a right even to be told that one is adopted (see, e.g., C. Bridge and H. Swindells, Adoption: The Modern Law (Bristol 2003), p. 255). For a recent general analysis of this topic, see A. Diver, A Law of Blood-ties - The 'Right' to Access Genetic Ancestry (Cham 2014).

130 See Dr. Hughes and my previous acknowledgement ("Post-adoption Photographs", p. 403) that it would be "fruitless" in the context of the welfare principle merely to argue that less weight should be given to the interests of one set of adults and more should be given to those of another set of adults. 
that "the notion that adopted children belong to another family with whom contact must be maintained was disconcerting and hurtful to adoptive parents and off-putting to potential adopters". ${ }^{131}$ His view goes some way to explaining his surprisingly explicit suggestion in his foreword to the relevant Government consultation document that "birth family contact, including letterbox contact, should only take place when the adoptive parents", and not apparently the court, are "satisfied that it continues to be in the interests of their child". ${ }^{132}$ Implausibly, the main body of the paper similarly asserted that "[a]ny further contact between their child and their child's birth parents is now a matter exclusively for the adoptive family", albeit that at least it almost immediately conceded that "[a]doptive parents are only obligated to maintain contact where a contact order has been made". ${ }^{133}$ Sir Martin's view could place such adoptive parents in a stronger position than all other types of parent once a matter concerning a child's upbringing comes before a court, putting this area at odds with the rest of child law. ${ }^{134}$

Even if Sir Martin's position could be said to be reflected in substance in the pre-existing law let alone under the Children and Families Act, it is unacceptable as a formal state of affairs. If adoption is to remain a means of providing permanence for children rather than a service for prospective adopters, and even if some prospective adoptive parents are indeed deterred by the idea of post-adoption contact, acceptable adopters may need to have a thicker skin than is implied by Sir Martin in the interests of the child's welfare. Indeed, Neil et al express a fear that a restrictive approach to post-adoption contact could convey an undesirable "message" to prospective and actual adopters that fails to reflect "adopted children's need for open communication about adoption and acceptance of the child's birth heritage". ${ }^{135}$

In any case, Sir Martin's view conflicts with the empirical finding that "virtually no [actual] adoptive parents felt that the contact had negatively affected their relationship with the child, and about half of adoptive parents believed that direct contact had brought about, or would lead to, benefits in their relationship with the adopted child". ${ }^{136}$ Admittedly, Neil et al suggested that

\footnotetext{
${ }^{131}$ Select Committee on Adoption Legislation, Adoption: Post-Legislative Scrutiny Report, at [261].

132 Department for Education, Contact Arrangements for Children: A Call for Views (London 2012), p. 2 (emphasis added). Cf. Department for Education, Call for Views: Adoption Contact Arrangements and Sibling Placements. Summary of Feedback and Government Response.

${ }^{133}$ Department for Education, Contact Arrangements for Children: A Call for Views, at [40].

${ }^{134}$ See, e.g., Prince v Massachusetts (1944) 321 U.S. 158, 170 (Rutledge J.), cited in Re S; Newcastle City Council v Z [2005] EWHC 1490 (Fam), [2007] 1 F.L.R. 861, at [54] (Munby J.).

${ }^{135}$ Neil et al, "Contact Arrangements for Adopted Children", at [20].

${ }^{136}$ Ibid., at para. [13].
} 
contact is most beneficial "where birth relatives support the child's placement in the adoptive family and where adoptive parents have an open attitude about adoption", ${ }^{137}$ which might cast doubt on the utility of ordered contact where the child has been adopted without parental consent and the adoptive parents are opposed to contact. But it should be noted that both courts ${ }^{138}$ and the legislature $^{139}$ are willing to go to some lengths to order and enforce contact where two legal parents' relationship has broken down except in unusual circumstances where that is not consistent with the welfare of the child. Moreover, Neil et al also found that "attitudes of both adoptive parents and birth relatives are not necessarily fixed" and "[b]oth adopters and birth relatives are sometimes more able to accept each other following the finality of the adoption order", ${ }^{140}$ suggesting that an order encouraging contact in the early stages may lead to supportive contact in the longer term.

The reforms in the Children and Families Act, however (if they are to have any substantive effect), create the risk that genuine investigations on the appropriateness of ordered post-adoption contact in the cases of individual children will occur even less frequently than they do under the current law, and that would clearly bring law and practice even further out of line unless local authorities were extremely strongly influenced by the policy messages sent out by the Act. ${ }^{141}$

\section{A Human Rights Audit}

It is unfortunate that the Joint Committee on Human Rights did not consider the proposed sections $51 \mathrm{~A}$ and $51 \mathrm{~B}$ in depth in its legislative scrutiny report on the Children and Families Bill. ${ }^{142}$ The present sub-section of this article, however, considers the reforms from a human rights standpoint. Human rights obligations, of course, (uneasily) ${ }^{143}$ overlap with but are distinct from the welfarebased considerations that in principle govern purely domestic child law. The European Convention

\footnotetext{
${ }^{137}$ Ibid., at para. [18].

${ }^{138}$ See, e.g., Re H (Contact Order) (No. 2) [2002] 1 F.L.R. 22.

${ }^{139}$ See, e.g., Children Act 1989, ss. 11A-11P, which are finessed and expanded by the Children and Families Act 2014 , sch. 2 .

${ }^{140}$ Neil et al, "Contact Arrangements for Adopted Children", at [18].

${ }^{141}$ For its part, the draft statutory guidance for local authorities etc. that is intended to take effect once the relevant provisions of the Act come into force claims that there is "no general presumption for or against contact", but also asserts that "there is no duty to endeavour to promote contact" (Department for Education, Statutory Guidance on Adoption: For local authorities, Voluntary adoption Agencies and Adoption Support Agencies (London 2014), p. 57.

142 Joint Committee on Human Rights, Legislative Scrutiny: Children and Families Bill; Energy Bill.

${ }^{143}$ See, e.g., D. Bonner, H. Fenwick and S. Harris-Short, "Judicial Approaches to the HRA" (2003) 52 International \& Comparative Law Quarterly 549
} 
on Human Rights is considered first, with a focus on the right to respect for family life under Article 8 , before the article moves on to consider the implications of the UN Convention on the Rights of the Child for post-adoption contact.

\section{The European Convention on Human Rights}

An adoption order is a clear prima facie infringement of the child's and the natural parents' Article 8 rights to respect for family life, albeit one that can be justified under Article 8(2). Lady Hale and Fortin suggest that " $[\mathrm{t}]$ he ability of birth parents to retain some contact with their child may...help to make compulsory adoption more Convention compliant", ${ }^{144}$ while Choudhry and Herring express the view that Article 8 requires a refusal to grant post-adoption contact to be justified. ${ }^{145}$ Bainham has similarly contemplated the possibility of Article 8-based challenges by natural parents to postadoption contact decisions, ${ }^{146}$ though elsewhere he implies that "existing kinship links and contacts" can truly be preserved only by avoiding full adoption altogether. ${ }^{147}$

In $R e J$, however, the Court of Appeal gave no consideration to the question whether the adopted child had an Article 8 right to respect for family life vis-à-vis her natural parents once her adoption occurred, and did say that it was "very far from obvious" that the natural parents" rights to respect for family life with the child could survive the adoption at all, ${ }^{148}$ irrespective of whether interference with them could be justified under Article 8(2). This prior question whether the (presumably largely symmetrical) Article 8 "family life" rights of birth parents and adopted child vis-à-vis each other continued post-adoption had received little real attention in Strasbourg at that time. $^{149}$

\footnotetext{
${ }^{144}$ B. Hale. and J. Fortin, "Legal Issues in the Care and Treatment of Children with Mental Health Problems" in M. Rutter et al (eds.), Rutter's Child and Adolescent Psychiatry, 5th edn. (Oxford 2008) p. 102.

${ }^{145}$ S. Choudhry and J. Herring, European Human Rights and Family Law (Oxford 2010), p. 334.

${ }^{146}$ A. Bainham, Children: The Modern Law, 3rd ed. (Bristol 2005), pp. 300-301.

${ }^{147}$ A. Bainham, "Arguments about Parentage' [2008] C.L.J. 322, 349-351. Cf. Smith and Logan, "Adoptive Parenthood as a "Legal Fiction" for an argument that a "transplant" model of adoption actually facilitates post-adoption contact by conferring the status of parenthood and making adoptive parents feel confident enough to allow such contact.

${ }^{148}$ [2010] EWCA Civ 581, at [43] (Lord Neuberger M.R, giving the judgment of the Court).

${ }^{149}$ See Hughes and Sloan, "Post-adoption Photographs", pp. 405-410 for discussion.
} 
In $R$ and $H v$ United Kingdom, ${ }^{150}$ decided after Re $J$, some natural parents complained that the Northern Ireland High Court violated their right to respect for family life under Article 8 by freeing their child for adoption without parental consent. ${ }^{151}$ The parents had unsuccessfully argued, inter alia, that their refusal to consent was reasonable because it was unclear whether adopters who were open to post-adoption contact could be found. The judge's decision was upheld by the Court of Appeal ${ }^{152}$ and the House of Lords, with Lady Hale dissenting. ${ }^{153}$ The claim before the European Court failed, but some of its analysis (while limited) suggests that Article 8 is generally applicable to the issue of post-adoption contact. For example, the Court was persuaded by the argument that the Health and Social Services Trust responsible for the adoption should have been given six months to find adopters willing to consent to post-adoption contact before a freeing order was issued. ${ }^{154}$ Ultimately, however, the European Court was satisfied that the directions made by the Court of Appeal placed sufficient emphasis on post-adoption contact. It therefore rejected the suggestion that "the domestic courts allowed [the child] to be freed for adoption without proper regard for the fact that her interests, and those of the applicants, were best served by post-adoption contact". ${ }^{155}$ While the Court did not expressly state that Article 8 encompasses post-adoption contact, and while $R$ and $H$ raised the broader issue of approving adoption without the consent of the natural parents, the significance that the Court implicitly attached to post-adoption contact suggests that Article 8 is relevant to this issue.

In Aune v Norway, also decided after the English Court of Appeal gave judgment in Re J, the European Court was presented with a case from a legal system where post-adoption contact could not be ordered at all and would inevitably be left to the discretion of the adoptive parents. ${ }^{156}$ On the facts of the case, all of the domestic organs had found that there was "almost absolute" certainty that the adoptive parents would remain open to contact between the relevant child and biological family. ${ }^{157}$ The European Court unanimously held that "the disputed measures did not in fact prevent the applicant from continuing to have a personal relationship with [the child] and did

\footnotetext{
${ }^{150}$ (Application no. 35348/06) [2011] 2 F.L.R. 1236.

${ }^{151} \operatorname{Re} N$ [2005] NIFam 5. For a summary of the relevant Northern Irish Law (based on the English Adoption Act 1976) and a brief comparison with the English Adoption and Children Act 2002, see $R$ and Hv United Kingdom (Application no 35348/06), at [43]-[49].

${ }^{152}$ Down Lisburn Health and Social Services Trust $v$ H and Another [2005] NICA 47(1).

153 [2006] UKHL 36, [2007] 1 F.L.R. 121.

${ }^{154}$ (Application no. 35348/06), at [87].

155 Ibid.

156 (Application no. 52502/07) (2012) 54 E.H.R.R. 32.

${ }^{157}$ Ibid., at para. [75].
} 
not result in 'cutting him off from his roots' with respect to contact with his biological mother". 158 The Court also held, however, that the domestic authorities "could reasonably consider that the applicant's interest in maintaining a legal right of contact was outweighed by the interest in authorising adoption". ${ }^{159}$ It was therefore satisfied that "the decision to deprive the applicant of parental responsibilities and to authorise the adoption was supported by relevant and sufficient reasons and, bearing in mind the national margin of appreciation, was proportionate to the legitimate aim of protecting [the child's] best interests". ${ }^{160}$ This indirectly suggests that a lack of post-adoption contact could in principle breach Article 8, but again the matter is far from clear and the decision might also suggest that the European Convention imposes no obligation for a state even to provide a mechanism whereby post-adoption can be ordered. Like $R$ and $H$, moreover, Aune was significantly concerned with the broader issue of adoption itself in the absence of parental consent. ${ }^{161}$ Finally, while IS $v$ Germany involves post-adoption contact, ${ }^{162}$ only the Statement of Facts and Questions to the Parties appear to be available at the time of writing and it can provide no further guidance on this issue.

Where a child is taken into state care (but not adopted), the Strasbourg Court has emphasised that "a measure as radical as the total severance of contact" with a parent can also be justified "only in exceptional circumstances", ${ }^{163}$ and that "any measures implementing temporary care should be consistent with the ultimate aim of reuniting the natural parents and the child". ${ }^{164}$ In the light of its strong opposition to severing a child from its roots through adoption other than in the most exceptional circumstances, ${ }^{165}$ it would be undesirable on policy grounds for the European Court retrospectively to increase the magnitude of interference with an Article 8 right caused by an adoption by holding that it eliminated "family life" that had previously existed. Paradoxically, however, the court's own emphasis on the draconian and exceptional nature of adoption as regards family life may well have made it more difficult to sustain an argument that family life for the purposes of Article 8 subsists after adoption occurs.

\footnotetext{
${ }^{158}$ Ibid., at para. [78].

${ }^{159}$ Ibid.

${ }^{160}$ Ibid., at para. [79].

${ }^{161}$ See, similarly, KS v United Kingdom (Application No. 62110/10) (2012) 55 E.H.R.R. SE15 (admissibility decision).

${ }^{162}$ IS v Germany (Application no. 31021/08) (HUDOC).

${ }^{163} S$ and $G$ v Italy (Application no. 39221/98) [2000] 2 F.L.R. 771, at [170].

${ }^{164} K$ and $T v$ Finland (Application no. 25702/94) [2001] 2 F.L.R. 707, at [178].

165 Görgülü v Germany (Application no. 74969/01) [2004] 1 F.L.R. 894, at [48].
} 
In any case, the Court's approach to adoption in general is distinctly ambivalent. In $Y C v$ United Kingdom, the majority of Court asserted both that "in cases concerning the placing of a child for adoption, which entails the permanent severance of family ties, the best interests of the child are paramount", and that "family ties may only be severed in very exceptional circumstances and...everything must be done to preserve personal relations and, where appropriate, to 'rebuild' the family". ${ }^{166}$ Lord Wilson, for his part, has described the decision as demonstrating "the high degree of justification which article 8 demands of a determination that a child should be adopted or placed in care with a view to adoption", ${ }^{167}$ but post-adoption contact was not directly addressed in the judgment in $Y C$.

One case in which an adopted person sought to invoke a right to respect for family life with a birth family post-adoption was Odièvre v France. ${ }^{168}$ The applicant challenged the French system of anonymous births which prevented her from accessing information about her natural mother. She argued that "her request for information about strictly personal aspects of her history and childhood came within the scope of Article 8 of the Convention" and that "[e]stablishing her basic identity was an integral part not only of her 'private life', but also of her 'family life' with her natural family, with whom she hoped to establish emotional ties...". ${ }^{169}$ This was contested by the French Government, which argued that "the guarantee of the right to respect for family life under Article 8 presupposed the existence of a family", and that the case law required there "to be at the very least close personal ties". ${ }^{170}$ Applying this to the facts of Odièvre, the Government argued that "no family life within the meaning of Article 8...existed between the applicant and her natural mother", on the basis that, "the applicant had never met her mother, while the latter had at no point expressed any interest in the applicant or regarded her as her child". ${ }^{171}$

In any case, the European Court of Human Rights offered no insight into the question whether the applicant in Odièvre could have a right to respect for family life in relation to her natural parents. It skirted the issue and held that as "the applicant's purpose [was] not to call into question her relationship with her adoptive parents but to discover the circumstances in which she was born and abandoned, including the identity of her natural parents and brother" the court should

\footnotetext{
${ }^{166}$ (Application no. 4547/10) [2012] 2 FLR 332, at [134] (judgment of the majority). See C. Simmonds, "Paramountcy and the ECHR: A Conflict Resolved?" [2012] C.L.J. 498 for analysis of the case.

${ }^{167} \operatorname{Re} B$ [2013] UKSC 33, [34].

168 (Application no. 42326/98) [2003] 1 F.C.R. 621.

${ }^{169}$ Ibid., at [25].

${ }^{170}$ Ibid., at [26].

${ }^{171}$ Ibid.
} 
consider the case "from the perspective of private life, not family life, since the applicant's claim... is based on her inability to gain access to information about her origins". ${ }^{172}$

The Court in Odièvre found that the private life provision in Article 8 was applicable although it afforded a wide margin of appreciation to the state and found that the right had not been violated in this case. This analysis, while more concerned with information than contact, fits with Harris-Short's contention that it is easier to fit post-adoption contact within "private life" as compared to "family life", ${ }^{173}$ and the European Court has explicitly asserted that close relationships short of "family life" would generally fall within the scope of "private life". ${ }^{174}$ Dr. Hughes and I have discussed the "private life" implications of post-adoption contact in detail elsewhere. ${ }^{175}$

It can be seen that the Article 8 implications of post-adoption contact are not clear-cut, reducing the usefulness of the Convention in this context. But if there are Article 8-based problems with English Law's approach to the matter, these are surely worsened by the Act if it brings about a change in approach. The attempt to reduce the scope for an application for post-adoption contact even to be heard risks violating the procedural requirements of Article 8, which the European Court has emphasised mean that "the decision-making process involved in measures of interference must be fair and such as to afford due respect to the interests safeguarded by" that Article. ${ }^{176}$ While the fact that the restriction on hearings is at least formally based on a perceived harm to a child might ultimately mean that the interference can be justified under Article 8(2), and the existence of Article 8 rights between adopter and adoptee must be borne in mind, ${ }^{177}$ this will be a matter for ripe debate once the post-adoption contact provisions in the Children and Families Act come into effect.

\section{The UN Convention on the Rights of the Child}

Unlike the ECHR, the UNCRC as a whole has not yet been incorporated into English law, ${ }^{178}$ which is a state of affairs that continues to cause concern for the UN Committee on the Rights of the Child

\footnotetext{
${ }^{172}$ Ibid, at [28].

${ }^{173}$ S. Harris-Short, "Making and Breaking Family Life: Adoption, the State and Human Rights" (2008) 35 Journal of Law and Society 28, 40 .

${ }^{174}$ See, e.g., Anayo v Germany (Application no. 20578/07) [2011] 1 F.L.R. 1883, at [58].

${ }^{175}$ Hughes and Sloan, "Post-adoption Photographs", 410-414.

${ }^{176} P, C$ and $S v$ United Kingdom (Application no. 56547/00) [2002] 3 F.C.R. 1, at [119]. See also Article 6 on the right to a fair hearing.

${ }^{177}$ See, e.g., Pini v Romania (78028/01) (2005) 40 E.H.R.R. 13.

178 See, generally, G. van Bueren, "The United Nations Convention on the Rights of the Child: The Necessity of Incorporation into United Kingdom Law" [1992] Family Law 373; A. MacDonald, "Bringing Rights Home for
} 
(the Committee). ${ }^{179}$ Lady Hale has nevertheless emphasised that the UNCRC imposes "binding obligation[s] in international law". ${ }^{180}$ Moreover, in a Supreme Court judgment citing my work on whether the English Law on adoption decisions per se is compatible with the UNCRC, ${ }^{181}$ Lord Neuberger said explicitly that "the 2002 Act must be construed and applied bearing in mind the provisions of the UN Convention on the Rights of the Child 1989". ${ }^{182}$

Article 21 of the UNCRC requires states inter alia to "ensure that the best interests of the child shall be the paramount consideration" in the context of adoption. ${ }^{183}$ But as Hodgkin and Newell emphasise in Unicef's Implementation Handbook, "[t]he Convention is indivisible and its articles interdependent", meaning that "Article 21 should not be considered in isolation". ${ }^{184}$ This has significant implications, since the other provisions of the Convention might provide clues as to the meaning of "best interests" (a notoriously uncertain concept) ${ }^{185}$ under Article 21. This is true notwithstanding the fact that those other provisions are themselves qualified, and that the notion of indivisibility of rights is clearly problematic where multiple rights appear to conflict.

Article 21 of the UNCRC must therefore be read alongside several of its other provisions. Article 7(1), for example, states that a child has "as far as possible, the right to know and be cared for by his or her parents". Hodgkin and Newell note that the phrase "as far as possible" "appear[s]

Children: Arguing the UNCRC" [2009] Family Law 1073; J. Fortin, Children's Rights and the Developing Law, 3rd ed. (Cambridge 2009), pp. 47-54. Cf. Rights of Children and Young Persons Measure (Wales) 2011, and Children and Families Act 2014, s. 107.

${ }^{179}$ Committee on the Rights of the Child, "Consideration of Reports submitted by State[ ] Parties under Article 44 of the Convention: Concluding Observations - United Kingdom of Great Britain and Northern Ireland" (Third and Fourth Reports) (CRC/C/GBR/CO/4, 2008), at [10]. See, generally, Committee on the Rights of the Child, "General Comment No 5 (2003): General Measures of Implementation of the Convention on the Rights of the Child (arts 4, 42 and 44, para 6)" (CRC/GC/2003/5, 2003).

${ }^{180}$ ZH (Tanzania) v Secretary of State for the Home Department [2011] UKSC 4, [2011] 2 W.L.R. 148, at [23]. See also, e.g. U. Kilkelly, "The CRC at 21: Assessing the Legal Impact" (2011) 62 Northern Ireland Legal Quarterly 143, 144.

${ }^{181} \operatorname{Re} B$ [2013] UKSC 33, at [103]-[104], citing Sloan, "Conflicting Rights".

${ }^{182} \operatorname{Re} B$ [2013] UKSC 33, at [73].

${ }^{183}$ See, e.g., Committee on the Rights of the Child, "Consideration of Reports Submitted by State[ ] Parties under Article 44 of the Convention: Concluding Observations - France" (Second Report) (CRC/C/15/Add.240, 2004).

${ }^{184}$ R. Hodgkin and P. Newell, Implementation Handbook for the Convention on the Rights of the Child, 3rd ed. (Geneva 2007), p. 303.

${ }^{185}$ See, e.g., Reece, "The Paramountcy Principle". 
to provide a much stricter and less subjective qualification than 'best interests", although they concede that consideration of what is "possible" must include consideration of "best interests". ${ }^{186}$

In addition to Article 7, Article 8(1) obliges states to respect a child's right to his or her identity and "family relations". It is limited to those relations recognised by law and purports to prohibit only "unlawful" interference, but this has not prevented the Committee on the Rights of the Child from criticising states' approach to identity even when the relevant rules are enshrined in national law. ${ }^{187}$ Logically, Hodgkin and Newell do not consider that a state could use its own national law substantially to limit the scope of this right. ${ }^{188}$ A similar argument could be made in relation to Article 7, which requires states to "ensure the implementation of the[ ] rights [it confers] in accordance with their national law and their obligations under the relevant international instruments". 189

Moreover, Article 9 mandates states to ensure that "a child shall not be separated from his or her parents against their will, except when competent authorities subject to judicial review determine, in accordance with applicable law and procedures, that such separation is necessary for the best interests of the child". 190 Those best interests, in turn, can be determined only via due consideration of the child's relationship with the parents.

A complication as regards the rights of a child post-adoption is the following declaration, made by the UK Government upon ratification of the Convention:

The United Kingdom interprets the references in the Convention to "parents" to mean only those persons who, as a matter of national law, are treated as parents. This includes cases where the law regards a child as having only one parent, for example where a child has been adopted by one person only... ${ }^{191}$

\footnotetext{
${ }^{186}$ Hodgkin and Newell, Implementation Handbook for the Convention on the Rights of the Child, p. 107.

${ }^{187}$ See, e.g., Committee on the Rights of the Child, "Consideration of Reports Submitted by State[ ] Parties under Article 44 of the Convention: Concluding Observations - Australia" (Fourth Report) (CRC/AUS/CO/4, 2012), at [37][38].

${ }^{188}$ Hodgkin and Newell, Implementation Handbook for the Convention on the Rights of the Child, pp. 107, 116.

${ }^{189} \mathrm{UNCRC}$, Article 7(2).

${ }^{190}$ UNCRC, Article 9(1).

${ }^{191}$ United Nations, "Multilateral Treaties Deposited with the Secretary-General",

Ch. IV, no. 11, available at <http://treaties.un.org/Pages/ViewDetails.aspx?src=TREATY\&mtdsg no=IV$\underline{11 \& \text { chapter }=4 \& l a n g=e n>}$ (last accessed 31 March 2014).
} 
On this interpretation, any reference to "parents" apparently becomes a reference to the adoptive parents, and not the birth parents, once an adoption order is (validly) made. ${ }^{192}$ Nevertheless, this declaration could in itself be said to jeopardise the child's right to establish his identity even if it is not possible for his birth parents to care for him or her. This is similar to the difficulty that exists as regards the survival of Article 8 ECHR rights to respect for family life as between birth parent and child post-adoption, discussed in the previous sub-section.

In any event, post-adoption contact with birth relatives is particularly relevant in the light of the child's UNCRC rights to preserve his identity and (subject to the UK's declaration on the meaning of "parents") to know his parents, and the Committee has recently expressed concern about an Israeli statute that "allows hiding from a child the fact that he or she has been adopted". 193 Post-adoption contact could be seen as a way of protecting a child's identity-related rights in cases where adoption was deemed necessary in order to secure the outcome consistent with the best interests of the child.

Moreover, Article 9(3) of the UNCRC obliges states to "respect the right of the child who is separated from one or both parents to maintain personal relations and direct contact with both parents on a regular basis, except if it is contrary to the child's best interests". This provision would again be subject to the UK's declaration on the meaning of "parents", and Article 9 is not specifically aimed at full adoption. But Hodgkin and Newell cite poverty being a ground for adoption as an example of a provision that was incompatible with Article 9. ${ }^{194}$ They also deem "simple" adoption ${ }^{195}$ to be a practice within the scope of Article $9,{ }^{196}$ and make several references to Article 9 in the Handbook's chapter on Article 21. ${ }^{197}$ It also seems particularly appropriate to apply Article 9 to English adoption law, since there it has effectively become an extension of, or an alternative to, the care system. In any case, continuity of upbringing for the purposes of Article 20 has been interpreted to include contact with family members where the child has been adopted. ${ }^{198}$

\footnotetext{
${ }^{192}$ Cf. Hodgkin and Newell, Implementation Handbook for the Convention on the Rights of the Child, pp. 105-106.

${ }^{193}$ Committee on the Rights of the Child, "Consideration of Reports Submitted by State[ ] Parties under Article 44 of the Convention: Concluding Observations - Israel" (Second to Fourth Reports) (CRC/C/ISR/CO/2-44, 2013), at [31].

${ }^{194}$ Hodgkin and Newell, Implementation Handbook for the Convention on the Rights of the Child, p. 123. See, e.g., Committee on the Rights of the Child, "Consideration of Reports Submitted by State[ ] Parties under Article 44 of the Convention: Concluding Observations - France" (Third \& Fourth Reports) (CRC/C/FRA/CO/4, 2009), at [65].

195 "Simple adoption" is a defined at n. 1 above.

${ }^{196}$ Hodgkin and Newell, Implementation Handbook for the Convention on the Rights of the Child, p. 123.

${ }^{197}$ Ibid., pp. 293-300.

${ }^{198}$ Ibid., p. 289.
} 
However, the English courts' approach to post-adoption contact again has the potential to bring them into conflict with the UNCRC, in spite of Lord Neuberger's subsequent emphasis on the importance of the UNCRC in $R e B$. Admittedly and inevitably, the Court of Appeal in $R e J$ did attempt to justify their conclusion on the basis of the child's welfare, but we have seen that the decision was extremely deferential to the adoptive parents. Lord Neuberger's judgment in that case did not self-evidently demonstrate that that limited contact was "contrary" to the child's best interests as prima facie required by Article 9 given the other interests protected by the Convention, even if a supportable conclusion was reached on the facts. The restrictions in the Children and Families Act, apparently aimed at limiting circumstances where a full hearing on post-adoption contact will occur, clearly create further difficulties in this regard.

The restrictions on the availability of a full hearing also have the potential to prejudice the child's rights under Article 12 of the UNCRC. That Article requires state parties to "assure to the child who is capable of forming his or her own views the right to express those views freely in all matters affecting the child, the views of the child being given due weight in accordance with the age and maturity of the child". ${ }^{199}$ There is also a more specific right to "be provided the opportunity to be heard in any judicial and administrative proceedings affecting the child, either directly, or through a representative or an appropriate body, in a manner consistent with the procedural rules of national law". ${ }^{200}$ This is clearly a qualified right limited with reference to national law, and a child would be able to make representations on whether or not a birth parent should be given leave to apply for a post-adoption contact order. That said, the substance of the right to be heard might well be difficult to confer upon a child if the likelihood of a full hearing on the merits of post-adoption contact is reduced following the Act's passing. It is significant that the Committee on the Rights of the Child has emphasised the particular importance of Article 12 in the general context of adoption, "the 'best interests' of the child cannot be defined without consideration of the child's views". ${ }^{201}$

Once an adopted child has reached the age of 18 , he can choose to be placed on an “Adoption Contact Register" if he wishes to make contact with relatives. ${ }^{202}$ Details of relatives who wish to make contact are stored in another part of the register, and information can be disclosed in appropriate circumstances if there is a match. But this does not secure an adopted person's UNCRC

\footnotetext{
${ }^{199}$ UNCRC, Article 12(1).

${ }^{200}$ UNCRC, Article 12(2).

${ }^{201}$ Committee on the Rights of the Child, "General Comment No 12 (2009): The Right of the Child to be Heard" (CRC/C/GC/12, 2009), at [56].

${ }^{202}$ Adoption and Children Act 2002, ss. 80-81.
} 
rights while that person remains a child, particularly given the lack of a clear entitlement to be told that he or she is adopted ${ }^{203}$ or a willingness to order contact where the adoptive parents are opposed.

There are therefore several respects in which the compatibility of the both the pre-existing law (taken to include both legislative and judicial elements) and the 2014 Act with the UNCRC is open to question. That said, it has is also clear that there are weaknesses and conflicts inherent in the Convention itself, since it fails to provide, in Alston's words, "a specific and readily ascertainable recipe for resolving the inevitable tensions and conflicts that arise in a given situation among the different rights recognized". ${ }^{204}$ Whatever one's view of the merits of adoption and postadoption contact, the difficult process of implementing the UNCRC cannot easily be considered complete in England and Wales merely because the best interests of the child are expressed to be the paramount consideration in post-adoption decisions. ${ }^{205}$

\section{CONCLUSION}

The twin reforms in the Children and Families Act of procuring more adoptions out of care and purporting to be even more cautious about ordering post-adoption contact might have a certain logic to them. Indeed, they are consistent with the older philosophy that if adoption is truly appropriate, post-adoption contact is unlikely to be so. They are not, however, consistent with modern ideas about open adoption, or assertions like that in $M F$ to the effect that adoption and contact afterwards can be complementary rather than antagonistic. ${ }^{206}$ Moreover, they are not clearly underpinned by solid empirical evidence. If the state continues to insist on severing the legal ties between increasing numbers of its biologically related citizens, it should surely be all the more careful to preserve their de facto relationships when appropriate. Ultimately, the post-adoption contact reforms in the Children and Families Act either reflect the current law (in which case they are unnecessary and represent law reform for rhetorical purposes and without due consideration of the pre-existing law) or they risk introducing more of an effective presumption against post-adoption contact, which is

\footnotetext{
${ }^{203}$ See, e.g., Committee on the Rights of the Child, "Consideration of Reports Submitted by State[ ] Parties under Article 44 of the Convention: Concluding Observations - Canada" (Third \& Fourth Report) (CRC/C/CAN/CO/3-4, 2012), at [57]-[58] on the importance of ensuring that "information about the date and place of birth of adopted children and their biological parents are preserved".

204 P. Alston, "The Best Interests Principle: Towards a Reconciliation of Culture and Human Rights" (1994) 8 International Journal of Law and the Family 1, 2.

${ }^{205}$ I have made the same point in relation to pre-adoption decisions elsewhere: Sloan, "Conflicting Rights".

${ }^{206}$ [2013] EWHC 1838 (Fam), at [28(viii)] (Ryder L.J.).
} 
undesirable because it jeopardises individualised welfare-based decision-making and pays scant regard to the possible human rights claims of adopted children and their birth parents. ${ }^{207}$ In the course of its discussion, however, this article has also highlighted the limitations of international human rights treaties as regards providing clear answers on a particular and sensitive issue within family law. In any case, it is likely that the post-adoption contact provisions in the Children and Families Act will prove to be troublesome.

${ }^{207}$ See J. Herring, "The Welfare Principle and the Children Act: Presumably it's about Welfare?" (2014) 36 Journal of Social Welfare \& Family Law 14 for a general discussion about the undesirability of "presumptions" in the context of the welfare principle. 